\title{
Effect of the Air Channel Depth on the Efficiency of Photovoltaic/Thermal Sensor with a Parabolic Concentrator
}

\author{
Maifi Lyes ${ }^{1, *}$, Kerbache Tahar ${ }^{1}$, Hioual Ouided ${ }^{2}$ \\ ${ }^{1}$ Physical Chemistry of Semi-conductor Laboratory, University of Constantine, Algeria \\ ${ }^{2}$ Department of Informatics, Sciences \& Technology Faculty, University of Khenchela, Algeria
}

Copyright $\bigcirc 2016$ by authors, all rights reserved. Authors agree that this article remains permanently open access under the terms of the Creative Commons Attribution License 4.0 International License

\begin{abstract}
In this paper, a theoretical study of a photovoltaic/thermal air system with a parabolic concentrator is presented. The investigated system consists of a photovoltaic panel under which air is made to flow through an exchange in order to extract heat from the panel, thereby cooling the cells and hence increasing their efficiency. The global energy yield of the system is evaluated in clouding both the electrical output of the modal and the thermal energy of air. The energy balance equations of the whole system are computed using the GAUSS-SAIDEL method, allowing to estimate heat transfer from all the main components, the results show that the daily yield, of the system increases with air mass flow rate, and decreases with the exchanger channel width. results at solar irradiance of $1120 \mathrm{~W} / \mathrm{m}^{2}$ show that the combined PV/TH efficiency is increasing from $60 \%$ to $75 \%$ and mass flow necessary to maintain the cells temperature constant decreasing form 1.8 to $1.2 \mathrm{Kg} / \mathrm{s}$, at exchanger channel width varies from 0.35 to $0.05 \mathrm{~m}$.
\end{abstract}

Keywords Thermal, Photovoltaic, Cells Solar, Parabolic Concentrator, Permanent Regime, Heat Exchanger

\section{Introduction}

Renewable energy technologies currently supply $13.3 \%$ of the world's primary energy needs. Their future potential depends on exploiting the resources locally available and on overcoming the environmental challenges, as on well as winning public acceptance. Most forms of renewable energy are based on harnessing incoming solar radiation, which totals about 3.8 million EJ per year. A photovoltaic/thermal hybrid solar system is a combination of photovoltaic and solar thermal components which produces both electricity and heat from one integrated. A prototype of photovoltaic/thermal system using air or water as a cooling fluid to decrease the temperature of solar cell presented by kern et al in 1978 [1]. Since then considerable research was performed in order to reduce the cost of photovoltaic/thermal systems using new concentrating photovoltaic/thermal configurations [2-7]. Most of the effort was devoted to the optimization of the concentrator with a given exchanger geometry. We present here in numerical study of the effect of the exchanger channel width, and air mass flow rate a temperatures variation in the different layers of the prototype, and the total device energy yield.

\section{System Model}

The system model is divided in two part: one that calculates the thermal heat system parameters such as temperature $(\mathrm{T})$, thermal energy $(\mathrm{Q})$ and thermal efficiency ( $\eta$ th) of the sensor, and the second part is devoted to electric model, which calculates the electrical parameters of the solar concentrating photovoltaic/thermal air system as the current (I), voltage (V) the sensor performance and the generated electric power. The photovoltaic/thermal collector considered in this work is shown in Figure 1. Where the glass cover (in plastic) plays an important role to protect the sensor against the stone's throw, and the light reflected and concentrated on the solar cell by cylindro-parabolic concentrator (reflector). The focusing system is composed of two cylindro-parabolic concentrators. Each one has seven panels form (Generic $60 \mathrm{WP}$ polycrystalline), with 36 cells in series for each panel. The panels are connected in series along the direction of the system; they are glued and locked to keep surfaces cells clean. Fins are Fixed on the heat exchanger provide the good heat exchange to cool the solar cells. The heat exchanger bottom is covered with a good insulation to minimize heat losses to the ambient [8]. 


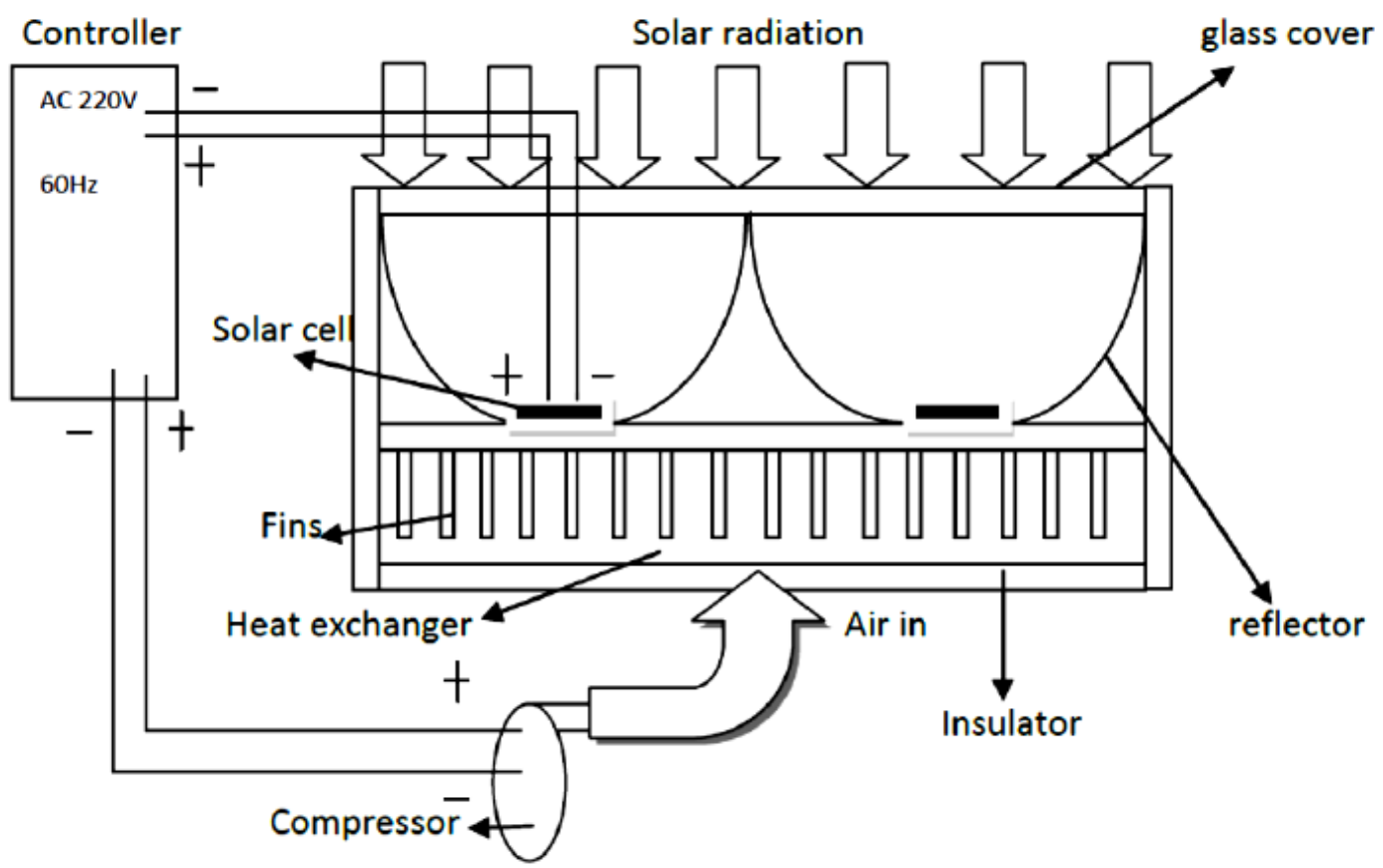

Figure 1. Schematic view of our sensor photovoltaic/thermal

\section{Thermal and Electrical Model}

Some Hypotheses are made as follows.

- Heat transfer is one-dimensional and in a steady state in the direction of the flow.

- The heat capacities of the glass, cylindro-parabolic concentrator, solar cell, fins, absorber and the insulating plate are negligible.

- The parabolic concentrator is ideal and all the incident radiation in the acceptance angle can reach the solar cells.

- The radiation passing through the interior of the parabolic concentrator is constant.

- The solar radiation converted into thermal energy is completely absorbed by the panels and solar absorber.

- The temperature of the solar cell and the absorber are uniform.

Based on these assumptions, the equations of energy can be written as:

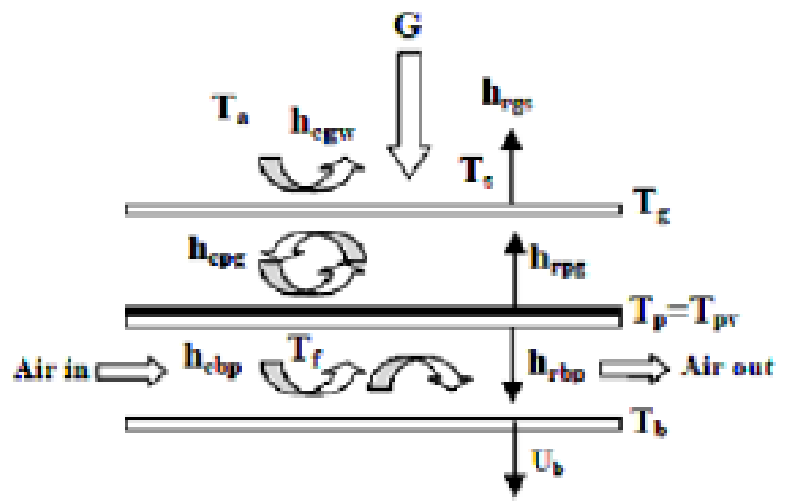

Figure 2. Thermal model of our thermal/photovoltaic sensor

\subsection{For the glass cover}

$$
\begin{array}{r}
w_{g} \varphi_{g} C_{g} \frac{\partial T_{g}}{\partial t}+\alpha_{\mathrm{g}} \mathrm{GC}\left(1+\tau_{\mathrm{g}} \rho_{\mathrm{g}} \rho_{\mathrm{R}}^{2 \mathrm{n}}\right)=\mathrm{h}_{\mathrm{rgs}}\left(\mathrm{T}_{\mathrm{g}}-\mathrm{T}_{\mathrm{s}}\right)+ \\
\mathrm{h}_{\mathrm{cgw}}\left(\mathrm{T}_{\mathrm{g}}-\mathrm{T}_{\mathrm{w}}\right)+\mathrm{h}_{\mathrm{cpg}}\left(\mathrm{T}_{\mathrm{g}}-\mathrm{T}_{\mathrm{p}}\right)+\frac{\mathrm{A}_{\mathrm{ct}}}{\mathrm{A}_{\mathrm{c}}} \mathrm{h}_{\mathrm{rpg}}\left(\mathrm{T}_{\mathrm{g}}-\mathrm{T}_{\mathrm{p}}\right)
\end{array}
$$

Where $\mathrm{n}$ is the average number of reflection for radiation inside the acceptance angle. And $\mathrm{C}$ is the ration concentrating.

\subsection{At the Photovoltaic Thermal Plate}

$$
\begin{gathered}
w_{p} \varphi_{p} C_{p} \frac{\partial T_{p}}{\partial t}+\tau_{\mathrm{g}} \alpha_{\mathrm{p}} \mathrm{G} \rho_{\mathrm{R}}^{\mathrm{n}} \mathrm{d}\left(1+\frac{\rho_{\mathrm{p}} \rho_{\mathrm{g}} \rho_{\mathrm{R}}^{2 \mathrm{n}}}{\mathrm{C}}\right)(1-\mathrm{P})+ \\
\tau_{\mathrm{g}} \alpha_{\mathrm{p}} \mathrm{GP} \rho_{\mathrm{R}}^{\mathrm{n}} \mathrm{d}\left(1+\frac{\rho_{\mathrm{pv}} \rho_{\mathrm{g}} \rho_{\mathrm{R}}^{2 \mathrm{n}}}{\mathrm{C}}\right)\left(1-\eta_{\mathrm{pv}}\right)=\frac{\mathrm{A}_{\mathrm{cb}}}{\mathrm{A}_{\mathrm{c}}} \mathrm{h}_{\mathrm{cpf}} \eta_{\mathrm{p}}\left(\mathrm{T}_{\mathrm{p}}-\right. \\
\left.\mathrm{T}_{\mathrm{f}}\right)+\frac{\mathrm{A}_{\mathrm{cb}}}{\mathrm{A}_{\mathrm{c}}} \mathrm{h}_{\mathrm{rpb}}\left(\mathrm{T}_{\mathrm{p}}-\mathrm{T}_{\mathrm{b}}\right)+\frac{\mathrm{A}_{\mathrm{ct}}}{\mathrm{A}_{\mathrm{c}}} \mathrm{h}_{\mathrm{cpg}}\left(\mathrm{T}_{\mathrm{P}}-\mathrm{T}_{\mathrm{f}}\right)+ \\
\frac{\mathrm{A}_{\mathrm{ct}}}{\mathrm{A}_{\mathrm{c}}} \mathrm{h}_{\mathrm{rpg}}\left(\mathrm{T}_{\mathrm{p}}-\mathrm{T}_{\mathrm{g}}\right)
\end{gathered}
$$

Where $\mathbf{d}$ is a correction of gap loss. $\mathbf{P}$ is the solar cell packing factor with [12].

$\eta_{p}:$ is the total efficiency.

$$
\eta_{p}=\frac{A_{c}+A_{f i n} \eta_{f i n}}{A_{c b}}
$$

And $\eta_{\text {fin }}$ is the fin efficiency

$$
\begin{gathered}
\eta_{\text {fin }}=\frac{\tanh \left(m_{f}\right)}{\lambda_{\text {fin }} \delta_{\text {fin }}} \\
m=\left(\frac{2 H_{\text {fin }}}{\eta_{\text {fin }} \delta_{\text {fin }}}\right)^{0.5}
\end{gathered}
$$

The solar cell efficiency depends on the cell temperature as given by ref [12]

$$
\eta_{p v}=\eta_{\text {ref }}\left(1-0.0054\left(T_{p}-298.15\right)\right)
$$


Where $\boldsymbol{\eta}_{\text {ref }}$ is a reference efficiency of solar cell at solar irradiance $1000 \mathrm{~W} / \mathrm{m}^{2}$ and temperature $\mathbf{T}_{\mathrm{ref}}=\mathbf{2 5}^{\circ} \mathbf{C}$. In this work $\boldsymbol{\eta}_{\text {ref }}$ is taken as $10 \%$.

\subsection{The Heat Exchanger}

$$
\begin{gathered}
\mathrm{w}_{\mathrm{pb}} \varphi_{f} C_{f} \frac{\partial T_{f}}{\partial t}+\frac{\mathrm{m}_{\mathrm{f}} \mathrm{C}_{\mathrm{f}}}{\mathrm{w}_{\mathrm{pb}}} \frac{\mathrm{dT}_{\mathrm{f}}}{\mathrm{dx}}= \\
\mathrm{h}_{\mathrm{cpf}}\left(\mathrm{T}_{\mathrm{b}}-\mathrm{T}_{\mathrm{f}}\right)+\frac{\mathrm{A}_{\mathrm{cb}}}{\mathrm{A}_{\mathrm{c}}} \mathrm{h}_{\mathrm{cpf}} \eta_{\mathrm{p}}\left(\mathrm{T}_{\mathrm{p}}-\mathrm{T}_{\mathrm{f}}\right)
\end{gathered}
$$

Where $\mathbf{m}_{\mathbf{p}}$ is mass flow rate $\left(\mathrm{kg} . \mathrm{s}^{-1}\right), \mathbf{C}_{\mathbf{f}}$ is specific heat $\left(\mathrm{J} \cdot \mathrm{kg}^{-1} \cdot \mathrm{k}^{-1}\right)$ and $\mathbf{w}$ is system width $(\mathrm{m})[11,12]$

\subsection{The Insulating Plate}

$$
\begin{gathered}
w_{b} \varphi_{b} C_{b} \frac{\partial T_{b}}{\partial t}+\mathrm{U}_{\mathrm{b}}\left(\mathrm{T}_{\mathrm{b}}-\mathrm{T}_{\mathrm{a}}\right)= \\
\mathrm{h}_{\mathrm{cpf}}\left(\mathrm{T}_{\mathrm{f}}-\mathrm{T}_{\mathrm{b}}\right)+\frac{\mathrm{A}_{\mathrm{cb}}}{\mathrm{A}_{\mathrm{c}}} \mathrm{h}_{\mathrm{rpb}}\left(\mathrm{T}_{\mathrm{p}}-\mathrm{T}_{\mathrm{b}}\right)
\end{gathered}
$$

The back loss coefficient $\mathbf{U}_{\mathbf{b}}$ is $0.0692 \mathrm{~W} \cdot \mathrm{m}^{2} . \mathrm{k}$ [12].

\section{Heat Transfer Coefficients}

In the above equations, radiative and convective heat transfer coefficients are calculated using the relations reported in refs [11-12].

The radiative heat transfer coefficients from glass cover to sky and absorber plate are taken as [12]

$$
h_{r g s}=\frac{\varepsilon_{g} \sigma\left(T_{g}^{4}-T_{s}^{4}\right)}{\left(T_{g}-T_{a}\right)}
$$

Where the equivalent sky temperature is evaluated as

$$
\begin{aligned}
T_{s} & =0.0552 T_{a}^{1.5} \\
\boldsymbol{h}_{r p g} & =\frac{\sigma\left(\left(\boldsymbol{T}_{p}^{2}+T_{g}^{2}\right)\left(T_{p}+T_{g}\right)\right.}{\left(\frac{1}{\varepsilon_{P}}+\frac{1}{\varepsilon_{g}}-1\right)} \\
\boldsymbol{h}_{r b p} & =\frac{\sigma\left(\left(T_{p}^{2}+T_{b}^{2}\right)\left(T_{p}+T_{b}\right)\right.}{\left(\frac{1}{\varepsilon_{P}}+\frac{1}{\varepsilon_{b}}-1\right)}
\end{aligned}
$$

The convective heat transfer coefficient of the wind is calculated by [11].

$$
h_{c g w}=2.8+3 V_{v}
$$

$\mathbf{V}_{\mathbf{v}}$ : The wind velocity is $3 \mathrm{~m} / \mathrm{s}$.

The natural convection heat transfer coefficient between the solar cells and glass cover is calculated as [12]

$$
\begin{gathered}
\left(\frac{\lambda_{\mathrm{f}}}{\mathrm{H}_{\mathrm{pg}}}\right)\left(1+1.44\left(1-\frac{1708}{\mathrm{R}_{\mathrm{a}} \cos \beta}\right)\left(1-\frac{\sin (1.8 \beta)^{1.6} 1708}{\mathrm{R}_{\mathrm{a}} \cos \beta}\right)+\right. \\
\left.\left(\mathrm{R}_{\mathrm{a}} \cos \beta / 5830\right)^{\frac{1}{3}}-1\right)
\end{gathered}
$$

The forced convective heat transfer coefficient of cooling air is calculated by $[10,11]$.

$$
\left(\frac{\lambda_{\mathrm{f}}}{\mathrm{D}}\right)\left(0.0158 \mathrm{R}_{\mathrm{e}}^{0.8}+\left(0.00181 \mathrm{R}_{\mathrm{e}}+2.92\right) \exp ^{-\frac{0.03795 \mathrm{X}}{\mathrm{D}}}\right.
$$$$
\mathrm{h}_{\mathrm{cpf}}=
$$

Where $\mathbf{R e}$ is Reynolds number [11]

\section{Method of Calculation}

We can write the equation 7 as:

$$
\frac{\mathrm{dT}_{\mathrm{f}}(\mathrm{x})}{\mathrm{dx}}+\mathrm{pT}_{\mathrm{f}}(\mathrm{x})=
$$

Where $\mathrm{p}$ and $\mathrm{q}$ are constants obtained by algebraic manipulations.

The boundary conditions are:

$$
\begin{aligned}
& \mathrm{T}_{\mathrm{f}}(\mathrm{x})=\mathrm{T}_{\mathrm{a}}, \text { at } \mathrm{x}=0 \\
& \mathrm{~T}_{\mathrm{f}}(\mathrm{x})=\mathrm{T}_{0}, \text { at } \mathrm{x}=\mathrm{L}
\end{aligned}
$$

The solution can be obtained as

$$
\mathrm{T}_{\mathrm{f}}(\mathrm{x})=\frac{\mathrm{q}}{\mathrm{p}}+\left(\mathrm{T}_{\mathrm{a}}-\frac{\mathrm{q}}{\mathrm{p}}\right) \exp ^{-\mathrm{px}}
$$

By grouping the four equations from equation 1 to equation 8 , we obtain a four variables matrix. In the equation $16, \mathrm{p}$ and $\mathrm{q}$ are the two unknown temperatures functions. An iterative algorithm is applied to determine these temperatures. In order to calculate the temperature of each cell of the photovoltaic concentrator, the panels is divided into $\mathrm{i}=252$ units of $0.031746 \mathrm{~m}$ length ( $\mathrm{i}$ is also the number of series cells in the collector). To start the calculation, initial values at $\mathrm{T}_{\mathrm{g}},\left(\mathrm{T}_{\mathrm{p}}=\mathrm{T}_{\mathrm{pv}}\right)$ and $\mathrm{T}_{\mathrm{b}}$ are introduced. The temperature $T_{f}$ of the in air flow at $x=0$, is equal to the ambient temperature. The new temperatures can be obtained from the matrix. Gauss-Seidel method is used to calculate the temperatures of each cell by an iterative process which is repeated until temperature values converge. Thus the components temperatures for the first cell can be determined. Applying it as the Intel to the next cell, the components temperatures for the second cell can be similarly calculated. By repeating this step, all temperatures for the different components can be determined. Using these temperatures, one can deduce the air mass flow influence on the cells and panel efficiency.

\section{Performance Parameters}

Performance parameters of the hybrid sensor thermal/photovoltaic are computed as following:

The thermal energy gained by the air flow through the system of thermal/photovoltaic is:

$$
Q_{t h}=\sum_{j=1}^{n} m_{p} \cdot C_{f} \cdot\left(T_{0, j}-T_{i, j}\right)
$$

The thermal efficiency of the system is:

$$
\eta_{\text {th }}=\frac{\sum_{\mathrm{j}=1}^{\mathrm{n}} \mathrm{m}_{\mathrm{p}} \mathrm{C}_{\mathrm{f}}\left(\mathrm{T}_{\mathrm{o}, \mathrm{j}}-\mathrm{T}_{\mathrm{i}, \mathrm{j}}\right)}{\mathrm{GC}}
$$

The electric power produced by the system is [10].

$$
Q_{p v}=\sum_{=1}^{n} \tau_{\mathrm{g}} \alpha_{\mathrm{pv}} \mathrm{GP} \rho_{\mathrm{R}}^{\mathrm{n}} \mathrm{d}\left(1+\frac{\rho_{\mathrm{pv}} \rho_{\mathrm{g}} \rho_{\mathrm{R}}^{2 \mathrm{n}}}{\mathrm{C}}\right)\left(\eta_{\mathrm{pv}, \mathrm{j}}\right)
$$

The electrical efficiency of the system is: 


$$
\eta_{\mathrm{pv}}=\frac{\mathrm{Qpv}_{\mathrm{pr}}}{\mathrm{GC}}
$$

The combined thermal/photovoltaic efficiency is the sum of photovoltaic and thermal efficiencies of the system.

$$
\eta_{\text {tot }}=\eta_{\mathrm{pv}}+\eta_{\mathrm{t}}-\eta_{\mathrm{c}}
$$

$\eta_{\mathrm{c}}$ : Efficiency of compressor

\section{Results and Discussion}

Some main thermo-physical parameters used in the calculation are presented in Table 1 .

Table 1. Thermo-physical and internal parameters of the system photovoltaic panels

\begin{tabular}{|c|c|c|c|}
\hline parameter & value & parameter & value \\
\hline$\alpha_{g}$ & 0.04 & $\mathrm{~d}$ & 0.95 \\
\hline$\alpha_{p}$ & 0.95 & $\mathrm{p}$ & 0.52 \\
\hline$\alpha_{p v}$ & 0.9 & $\varepsilon_{g}$ & 0.86 \\
\hline$\tau_{g}$ & 0.9 & $\varepsilon_{p}$ & 0.95 \\
\hline$\rho_{g}$ & 0.06 & $\varepsilon_{b}$ & 0.95 \\
\hline$\rho_{R}$ & 0.94 & $\sigma$ & $5.66 .10-8 \mathrm{Wm}^{-2} \mathrm{k}^{-4}$ \\
\hline$\rho_{P}$ & 0.05 & $\mathrm{U}_{\mathrm{p}}$ & $0.5 \mathrm{Wm}^{-2} \mathrm{k}^{-1}$ \\
\hline$\rho_{P V}$ & 0.05 & $\mathrm{C}_{\mathrm{f}}$ & $1008 \mathrm{JKg}^{-1} \mathrm{~K}^{-1}$ \\
\hline $\mathrm{n}$ & 0.61 & $\mathrm{C}$ & 2 \\
\hline
\end{tabular}

In practice, time variation of the enthalpy of the captor's components, namely the $\left(w \varphi C \frac{\partial T}{\partial t}\right)$ terms are negligible [13]. The time dependent values of solar irradiation $G$, and ambient temperature $T_{a}$, used for the calculation one shown on figure 3 .

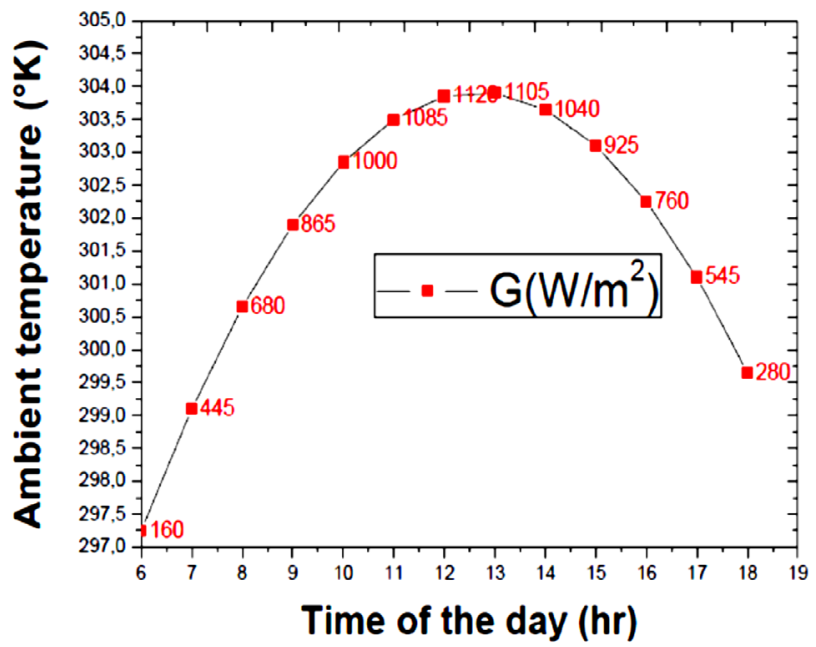

Figure 2. Mean hourly values of the global solar radiation $\mathrm{G}$ and the ambient temperature in Constantine.

Figure 3 and 4 show the effect of channel width of heat exchanger on the total efficiency and mass flow rate for $12 \mathrm{~h}$ of sunshine.

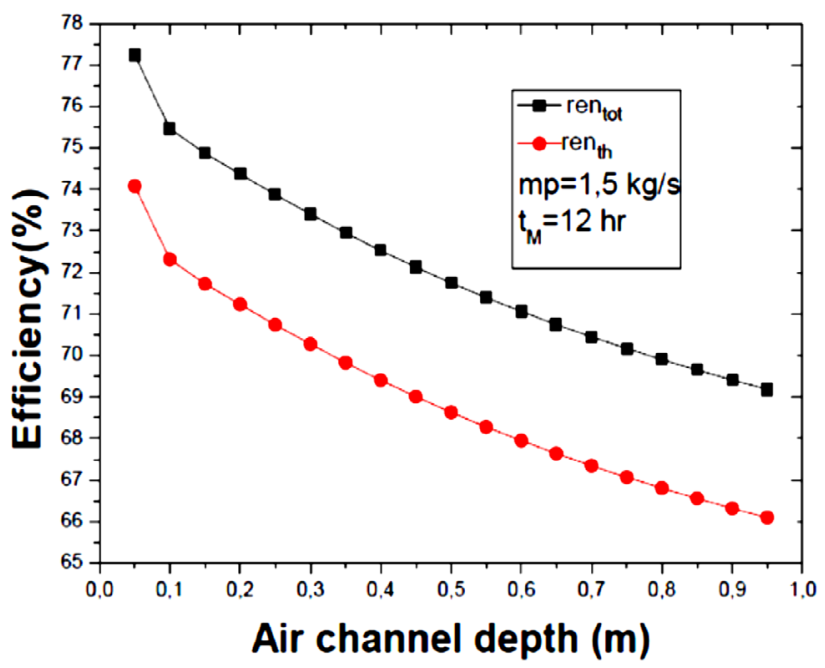

Figure 3. Effect of the total efficiency on the air channel width

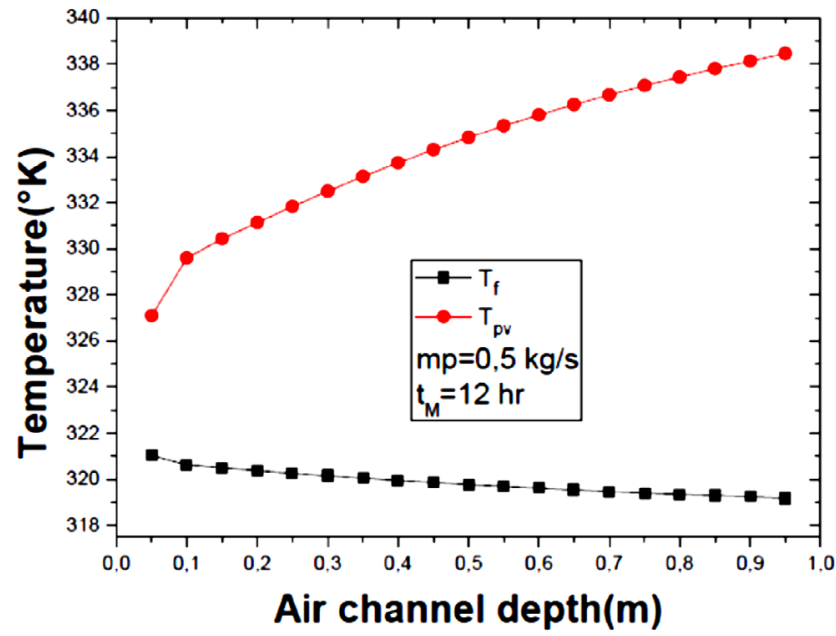

Figure 4. Effect of the cell temperature, and fluid temperature on the air channel width

Figure 5 and 6 shows the effect of channel width of heat exchanger on the efficiency of sensor and the outlet fluid temperature and cells temperature.

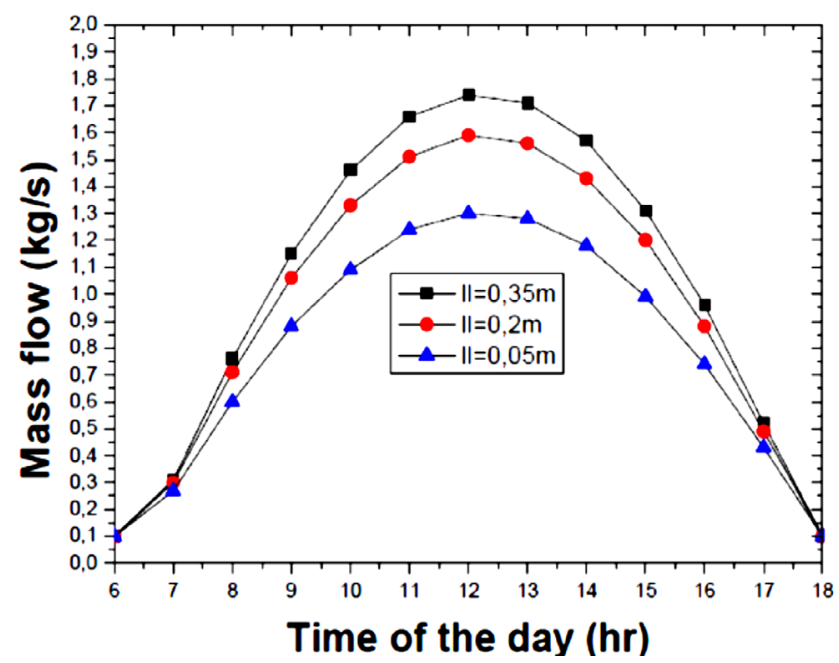

Figure 5. Effect of the air channel width on the hourly variations of the mass flow 


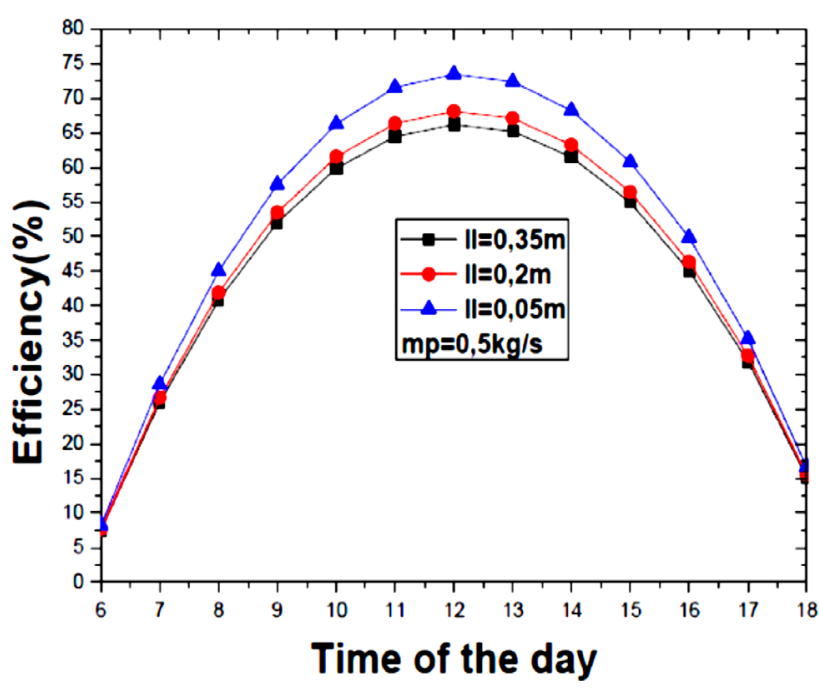

Figure 6. Effect of the air channel width on the hourly variations of the efficiency

It is observed that the mass flow necessary to maintain the cells temperature constant increases when one increases the air channel width of the heat exchanger (Figure 3).

This is explained by the fact that the heat exchanges convective internal in the sensor between air and the cells improved, when the distance between absorber and insulating plate, decreases.

The outlet air temperature and the efficiency of the system decrease with increasing air channel width (Figure 4 and 5) because the internal thermal convective exchanges deteriorate with increasing air channel width, the air flow rate being kept constant. But we showed that the cells temperature increases quickly with an increase of air channel width of the exchanger of heat, when mass flow of air maintained constant Figure 4.

It is observed Fig.7 that the daily output of the system decreases when one increases the air channel width of the heat exchanger. This is explained by the fact that the heat exchanges connectives internal in the sensor deteriorate, when the distance between absorber and insulating plate, increases, the mass flow of air being maintained constant.

\section{Conclusions}

In this study, heat transfer and the semiconductors $\mathrm{p}-\mathrm{n}$ junction equations are used to study effect of the air channel width of heat exchanger on efficiency for solar concentrating photovoltaic thermal air system the performance of a flat plate solar collector. A theoretical model for the energy analysis is presented. From this simulation it can be stated that. The efficiency and the fluid temperature of the concentrating photovoltaic thermal air system, increases with decreasing of channel width of heat exchanger and cell temperature decreases. Based on this analysis, the appropriate operating conditions for concentrating photovoltaic thermal air system could be determined with the given conditions and are useful for obtaining a higher useful energy rate and decreasing internal losses. We conclude that once the developed simulation model is successfully verified by experimental results, this model will useful at different operating conditions such as exchanger channel width, flow rates, inlet temperatures, sizing and so on.

\section{Nomenclature}

\begin{tabular}{|c|c|c|}
\hline A & Area & $\mathrm{m}^{2}$ \\
\hline $\mathrm{E}$ & Electrical energy & $\mathrm{W}$ \\
\hline $\mathrm{D}$ & hydraulic diameter & $\mathrm{m}$ \\
\hline $\mathrm{G}$ & Solar radiation & $\mathrm{W} \cdot \mathrm{m}^{-2}$ \\
\hline $\mathrm{h}$ & heat transfer coefficient & $\mathrm{W} \cdot \mathrm{m}^{-2} \cdot \mathrm{K}^{-1}$ \\
\hline $\mathrm{H}$ & Height & $\mathrm{m}$ \\
\hline $\mathrm{L}$ & length & $\mathrm{m}$ \\
\hline $\mathrm{V}$ & velocity & $\mathrm{m} \cdot \mathrm{s}^{-1}$ \\
\hline $\mathrm{m}$ & Mass flow rate & $\mathrm{kg} \cdot \mathrm{s}^{-1} \mathrm{~m}^{-2}$ \\
\hline Q & energy & $\mathrm{W}$ \\
\hline $\mathrm{Ra}$ & Rayleigh number & 1 \\
\hline $\mathrm{Re}$ & Reynolds number & l \\
\hline $\mathrm{T}$ & Temperature & ${ }^{\circ} \mathrm{K}$ \\
\hline $\mathrm{w}$ & thickness & $\mathrm{m}$ \\
\hline $\mathrm{x}$ & Direction variable & $\mathrm{m}$ \\
\hline \multicolumn{3}{|c|}{ Greek letters } \\
\hline$\alpha$ & Absorptivity & \\
\hline$\beta$ & Acceptance angle & $\circ$ \\
\hline$\eta$ & efficiency & \\
\hline$\tau$ & Transmitivity & \\
\hline$\rho$ & reflectivity & \\
\hline$\rho_{R}$ & reflector & \\
\hline$\lambda$ & Thermal conductivity & $\mathrm{W} \cdot \mathrm{m} \cdot \mathrm{K}^{-1}$ \\
\hline$\delta$ & Thickness & $\mathrm{m}$ \\
\hline$\varepsilon$ & Emissivity & \\
\hline$\varphi$ & density & $\mathrm{Kg} \cdot \mathrm{m}^{-3}$ \\
\hline$\sigma$ & Boltzmann number & $\mathrm{W} \cdot \mathrm{m}^{-2} \cdot \mathrm{K}^{-4}$ \\
\hline \multicolumn{3}{|c|}{ Subscripts } \\
\hline $\mathrm{a}$ & Ambient & \\
\hline $\mathrm{b}$ & Back pate & \\
\hline $\mathrm{c}$ & Convective & \\
\hline $\mathrm{cb}$ & Top surface of absorber plate & \\
\hline ct & Bottom surface of absorber plate & \\
\hline $\mathrm{g}$ & glass & \\
\hline $\mathrm{f}$ & fluid & \\
\hline $\mathrm{i}$ & inlet & \\
\hline o & outlet & \\
\hline $\mathrm{p}$ & Absorber plate & \\
\hline pv & Solar cell & \\
\hline $\mathrm{r}$ & radiative & \\
\hline $\mathrm{s}$ & sky & \\
\hline th & thermal & \\
\hline $\mathrm{w}$ & Ambient/ wind & \\
\hline
\end{tabular}




\section{REFERENCES}

[1] EC Kern Jr and M C Russel. Combined photovoltaic and thermal hybrid collector system, Proc. of 13th IEEE PVSC. (1978) 1153-1157.

[2] L.W. Florschuetz, Extension of the Hottel-Whillier model to the analysis of combined photovoltaic thermal flat collector, Sol. Energy. 22 (1979) 361-366.

[3] H.P. Garg, R.S Adhikari, Conventional hybrid photovoltaic thermal (PV/T) air heating collectors: Steady-state simulation, Renewable Energy. 11 (1997) 363-385.

[4] H.P. Garg and R.S. Adhikari, Performance analysis of a hybrid photovoltaic/thermal $(\mathrm{PV} / \mathrm{T})$ collector with integrated CPC troughs, Int. J. Energy. Res. 23 (1999) 1295-1304.

[5] G.R. Whitfield, R.W. Bentley, C.K. Weather by, B. Clive, The development of small concentrating pv systems, Proc. of 29th IEEE PVSC. New Orleans. (2002) 1377-1379.

[6] M.Y. Othman, B. Yatim, Performance analysis of a double-pass photovoltaic/thermal (PV/T) solar collector with CPC and fins, Renewable Energy. 30 (2005) 2005-2017.

[7] X. Chen, Y.M. Xuan, Y.G. Han, Investigation on performance of a solar thermophotovoltaic system, Sci. China. Ser. E-Tech. Sci. 51 (2008) 2285-2294.
[8] R. Ari, Optical and thermal properties of compound parabolic concentrators, Sol. Energy. 18 (1976) 497-511.

[9] K. Sopiana, H.T. Liu, S. Kakac, T.N. Veziroglu, Performance of a double pass photovoltaic thermal solar collector suitable for solar drying systems, Ener. Conv. Manage. 41 (2000) 353-365.

[10] G. Walker, Evaluating MPPT converter topologies using a MATLAB PV model, J. Electr. Electron. Eng. 21 (2001) 4956.

[11] R. Kadri, H. Andrei, J. P. Gaubert, T. Ivanovici, G. Champenois, P. Andrei, Modeling of the Photovoltaic Cell Circuit Parameters for Optimum Connection Model and Real-Time Emulator with Partial Shadow Conditions, Energy. 42 (2012) 57-67.

[12] Ramos Hernanz, JA., Campayo Martín, J.J., Zamora Belver, I., Larrañaga Lesaka, J., Zulueta Guerrero, E., Puelles Pérez, E, Modelling of Photovoltaic Module, Conference on Renewable Energies and Power Quality (ICREPQ'10) Granada (Spain), March, 2010.

[13] Donatien. Njomo, thermal behavior of a combined plastic-glass flat plate solar air collector, Rev.Gén.Therm.37 (1998) 973-980. 